\title{
PENGEMBANGAN PERANGKAT PEMBELAJARAN BAHASA INDONESIA (CERPEN) MODEL PEMBELAJARAN KOOPERATIF TIPE TEAMS GAMES TORNAMENTS (TGT) PADA SISWA KELAS X SMA NEGERI 11 MAKASSAR
}

\author{
Andi Karman \\ Fakultas Keguruan dan Ilmu Pendidikan Universitas Cokroaminoto Palopo \\ Jalan Latammacelling 19 Palopo, Sulawesi Selatan \\ e-mail: andikarman1@gmail.com
}

\begin{abstract}
Software Development Learning Indonesian (Short Story) Model Cooperative Learning Teams Games Tornaments (TGT) in Class X SMAN 11 Makassar. This research aims to develop learning tools with cooperative learning model type Teams Games Tournaments (TGT) in class X SMA Negeri 11 Makassar and expected an increase learning achievement of learners. Design test product designs in development using quantitative research, namely quantitative descriptive. This research was conducted in SMA Negeri 11 Makassar. The trial results is known that the learning device TGT learning model is effective and practical, the test results showed that the average score obtained by the students on achievement test is 87.68 of the ideal score of 100 with a standard deviation of 4.91 . Number 39 of 41 students or $92.6 \%$ meet the individual mastery. These data show that the classical completeness is reached. In general, the students responded positively to the learning device that digunakan.Tingkat teacher's ability to manage the process of cooperative learning teams tournamens games (TGT) are included in the category of very high, meaning that the teacher performance can be maintained.
\end{abstract}

\begin{abstract}
Abstrak: Pengembangan Perangkat Pembelajaran Bahasa Indonesia (Cerpen) Model Pembelajaran Kooperatif Tipe Teams Games Tornaments (TGT) pada Siswa Kelas X SMA Negeri 11 Makassar. Penelitian ini bertujuan untuk mengembangkan perangkat pembelajaran dengan model pembelajaran kooperatif tipe Teams Games Tournaments (TGT) pada siswa kelas X SMA Negeri 11 Makassar dan diharapkan adanya peningkatan prestasi belajar pada peserta didik. Desain uji coba produk pengembangan menggunakan desain dalam penelitian kuantitatif, yakni deskriptif kuantitatif. Penelitian ini dilaksanakan di SMA Negeri 11 Makassar. Hasil ujicoba diketahui bahwa perangkat pembelajaran model pembelajaran TGT bersifat efektif dan praktis, hasil ujicoba diperoleh bahwa skor rata-rata yang diperoleh siswa pada tes hasil belajar adalah 87,68 dari skor ideal 100 dengan standar deviasi 4,91. Jumlah 39 dari 41 siswa atau 92,6\% memenuhi ketuntasan individu. Data ini menunjukkan bahwa ketuntasan klasikal tercapai. Pada umumnya siswa memberikan respons yang positif terhadap perangkat pembelajaran yang digunakan.Tingkat kemampuan guru dalam mengelola proses pembelajaran kooperatif tipe teams games tournamens (TGT) termasuk dalam kategori sangat tinggi, artinya penampilan guru dapat dipertahankan.
\end{abstract}

Kata kunci: pengembangan, teams games tornaments, perangkat pembelajaran.

Fitrah manusia sejati adalah menjadi pelaku atau subjek bukan menjadi objek. Panggilan manusia sejati adalah menjadi pelaku yang sadar, bertindak mengatasi dunia serta realitas yang mungkin menindasnya. Dunia dan realitasnya ini bukan sesuatu yang ada dengan sendirinya, melainkan karena itu "harus diterima menurut apa adanya" sebagai suatu takdir atau semacam nasib yang tak terelakkan, seperti mitos. Manusia harus menggeluti dunia dan realitas dengan penuh sikap kritis, daya cipta dan atau mengandaikan perlunya sikap orientatif yang merupakan pengembangan bahasa pikiran (thought of language), yakni pada hakikatnya manusia mampu memahami keberadaan dirinya dan lingkungan dunianya yang dengan bekal 
pikiran dan tindakan.

Pendidikan pada hakikatnya adalah usaha membudayakan manusia atau memanusiakan manusia.Manusia adalah pribadi yang utuh dan kompleks, sehingga sulit dipelajari secara tuntas sebab hakikat manusia itu sendiri selalu berkembang mengikuti dinamika kehidupan. Perkembangan ilmu pengetahuan dan teknologi memaksa dunia pendidikan menyesuaikan diri pada perubahan yang serba kompleks pada kehidupan manusia.

Penguasaan ilmu pengetahuan dan teknologi sangat menentukan kemajuan suatu bangsa. Bangsa yang memiliki sumber daya manusia yang berkualitas tinggi akan menciptakan stabilitas nasional yang sehat dan dinamis serta berkembang dan mencapai kemakmuran yang berkeadilan. Dalam rangka merealisasikan upaya tersebut, wahana dan sarana yang paling strategis dan memberikan harapan adalah pendidikan sebab pendidikan merupakan proses peningkatan kualitas sumber daya manusia yang hasilnya diperlukan dalam pembangunan.

Bahasa Indonesia sebagai salah satu ilmu dasar, baik aspek penalarannya maupun aspek terapannya mempunyai peranan yang penting dalam upaya melestarikan bahasa persatuan. Hal ini berarti bahasa Indonesia perlu dibekalkan kepada setiap peserta didik. Ada banyak faktor yang memengaruhi tingkat keberhasilan pendidikan bahasa Indonesia, yaitu faktor siswa, guru, sarana dan prasarana. Masih terdapat siswa yang beranggapan negatif terhadap bahasa Indonesia.

Rendahnya hasil belajar siswa, khususnya bahasa Indonesia disebabkan karena strategi pembelajaran maupun pendekatan yang digunakan oleh guru kurang efektif, metode dan model pembelajaran yang kurang kreatif dan variatif sehingga muncul kecenderungan pengajaran berpusat pada guru. Secara operasional kebanyakan guru masih menggunakan pendekatan tradisional atau mekanistik yang menekankan pada proses keterampilan dan latihan. Guru lebih menitikberatkan pada pengajaran (teaching) sementara siswa pasif dan cenderung untuk menghafal konsep tanpa disertai pemahaman yang memadai. Oleh karena itu, sangat diperlukan adanya pembaharuan strategi pembelajaran maupun pendekatan yang digunakan oleh guru selama ini.
Pembaharuan dalam pengajaran bahasa Indonesia dimaksudkan untuk memperbaiki tujuan pengajaran yang selama ini masih menjadi penekanan dalam pembelajaran, yaitu dari fonem sampai wacana ataupun sastra antara lain puisi, cerpen dan drama yang menitikberatkan pada pemahaman konsep-konsep bahasa Indonesia yang lebih baik dan penggunaan strategi pemecahan masalah yang lebih efektif. Pembelajaran bahasa Indonesia tidak lagi mengutamakan pada penyerapan materi melalui pencapaian informasi, tetapi lebih mengutamakan pada pengembangan kemampuan dan proses informasi. Siswa diharapkan memiliki kemampuan berkomunikasi, berkolaborasi dengan siswa lainnya, serta menggunakan bahasa Indonesia untuk memecahkan masalah dalam kehidupan seharihari.

Salah satu model pembelajaran yang melibatkan para peserta didik secara aktif dalam memperoleh dan memahami konsep-konsep bahasa Indonesia secara benar, yaitu model pembelajaran kooperatif tipe Teams Games Tournaments (TGT). Belajar lebih baik dari sekadar mengingat. Siswa perlu dibiasakan untuk memecahkan masalah, menemukan sesuatu yang berguna bagi dirinya dan bergelut dengan ide-ide. Dalam pembelajaran kooperatif TGT ini, siswa merupakan pelaku utama dalam pembelajaran. Siswa diharapkan mampu berkomunikasi, berkolaborasi dengan siswa lainnya dan diharapkan mampu menggunakan bahasa Indonesia untuk memecahkan masalah dalam kehidupan sehari-hari dengan mengkonstruksi sendiri pengetahuan melalui manipulasi bendabenda nyata yang ada pada lingkungannya atau yang dapat dibayangkan.

Mengimplementasikan pembelajaran bahasa Indonesia di kelas, maka yang pertama harus dilakukan adalah penyusunan perangkat pembelajaran. Perangkat pembelajaran tersebut disusun mengacu pada karakteristik model pembelajaran kooperatif tipe TGT. Berdasarkan uraian tersebut penulis merasa perlu untuk melakukan penelitian dengan judul "Pengembangan Perangkat Pembelajaran Bahasa Indonesia (Cerpen) Model Pembelajaran Kooperatif tipe Teams Games Tornaments (TGT) pada Siswa Kelas X SMA Negeri 11 Makassar“. 


\section{METODE}

Proses kegiatan research and development berlangsung secara bersiklus, melalui tahapan: (1) pengkajian atau penelusuran awal topik-topik yang akan dikonstruksi atau direkonstruksi; (2) pengembangan produk model dari hasil temuan yang telah dicapai; (3) penguji cobaan model yang telah dikembangkan pada lokasi; dan dimana produk tersebut akan digunakan; dan (4) perbaikan model sesuai dengan temuan dalam situasi pendahuluan di lapangan.

Penelitian ini dilaksanakan melalui tiga tahap, yaitu tahap persiapan, tahap pelaksanaan, dan tahap analisis data. Uji coba produk dilakukan hanya terbatas pada uji perseorangan dan uji kelompok kecil. Dalam bagian ini secara berurutan dikemukakan desain uji coba, subjek uji coba, jenis data, instrumen pengumpulan data, dan teknik analisis data.

Desain uji coba produk pengembangan menggunakan desain dalam penelitian kuantitatif, yakni deskriptif kuantitatif. Penelitian ini dilaksanakan di SMA Negeri 11 Makassar dengan subjek uji coba adalah siswa Kelas $\mathrm{X}_{5}$ dengan jumlah siswa sebanyak 40 orang. Jenis data hasil uji coba di kelas yang digunakan hasil observasi dan skor siswa. Untuk memperoleh informasi tentang aktivitas siswa, aktivitas guru, dan pengelolaan pembelajaran kooperatif tipe TGT, dan tingkat penguasaan siswa terhadap materi yang telah diajarkan, dikembangkan instrumen-instrumen sebagai berikut:

a. Lembar Validasi Perangkat Pembelajaran

b. Lembar Pengamatan Aktivitas Siswa

c. Lembar Pengamatan Aktivitas Guru

d. Lembar Pengamatan Pengelolaan Pembelajaran Kooperatif tipe TGT

e. Respon Siswa terhadap Kegiatan Pembelajaran

f. Respon Guru Terhadap Kegiatan Pembelajaran

g. Tes Hasil Belajar

Data yang telah dikumpulkan dengan menggunakan instrumen-instrumen, selanjutnya dianalisis secara kuantitatif dan diarahkan untuk menjelaskan kevalidan, keefektifan dan kepraktisan perangkat pembelajaran yang tengah dikembangkan. Data yang diperoleh dari hasil validasi oleh para ahli dianalisis untuk menjelaskan kevalidan dan kelayakan penggunaan perangkat pembelajaran di kelas.

\section{HASIL DAN PEMBAHASAN}

Hasil

Pengembangan perangkat pembelajaran bahasa Indonesia model kooperatif tipe teams games tournamens (TGT) yang berdasarkan pada Model 4-D (Thiagarajan) terdiri dari empat tahap, yaitu tahap pembatasan (define), tahap perancangan (design), tahap pengembangan (develop) dan tahap penyebaran (disseminate).

Tabel 1. Rangkuman Hasil Validasi Perangkat Pembelajaran

\begin{tabular}{||l|c|c||}
\hline \multicolumn{1}{|c|}{ Perangkat } & $\begin{array}{c}\text { SKOR RATA- } \\
\text { RATA } \\
\text { PENILAIAN }\end{array}$ & STATUS \\
\hline Buku Siswa & 3,12 & $\mathrm{~V}$ \\
\hline Lembar Kerja Siswa & 3,33 & $\mathrm{~V}$ \\
\hline $\begin{array}{l}\text { Rencana Pelaksanaan } \\
\text { Pembelajaran }\end{array}$ & 3,3 & $\mathrm{~V}$ \\
\hline Tes Hasil Belajar & 3,39 & $\mathrm{SV}$ \\
\hline \hline
\end{tabular}

Dapat disimpulkan bahwa perangkatperangkat yang disebutkan pada tabel di atas sudah termasuk dalam kategori "Valid" ( $2,5 \leq \bar{V} \leq 3,5)$ dan kategori "Sangat Valid" ( $3,5 \leq \bar{V} \leq 4)$. Berdasarkan kriteria kevalidan, maka perangkat pembelajaran tersebut telah memiliki derajat validitas yang memadai dan layak untuk diujicobakan. Namun demikian, perangkat-perangkat tersebut menurut saran para ahli masih perlu diperbaiki/ ditambah.

\section{Analisis Deskriptif Hasil Pengembangan}

Berdasarkan hasil ujicoba perangkat pembelajaran yang meliputi: Buku Siswa (BS), Lembar Kerja Siswa (LKS), dan Rencana Pelaksanaan Pembelajaran (RPP) diperoleh data hasil tes belajar siswa, data hasil pengamatan aktivitas siswa, respons siswa terhadap kegiatan dan perangkat pembelajaran kooperatif tipe teams games tournamens (TGT), data hasil pengamatan aktivitas guru, dan data hasil pengamatan pengelolaan pembelajaran koopera- 
tif tipe TGT. Data-data inilah yang digunakan untuk mengetahui kepraktisan dan keefektifan perangkat pembelajaran kooperatif tipe teams games tournamens (TGT). Hasil analisis masing-masing data sebagai berikut:

\section{Hasil Belajar Siswa}

Tes hasil belajar diberikan ke siswa untuk memperoleh informasi tentang penguasaan siswa terhadap materi yang telah diajarkan. Hasil analisis deskriptif secara kuantitatif penguasaan bahasa Indonesia setelah diberi tindakan pada tes hasil belajar dapat dilihat pada tabel berikut:

Tabel 2. Statistik Skor Hasil Belajar Bahasan Indonesia Siswa Kelas X.5 SMA Negeri 11 Makassar

\begin{tabular}{||c||c|}
\hline Variabel & Nilai Statistik \\
\hline \hline Subjek Penelitian & 41 \\
\hline
\end{tabular}

\begin{tabular}{||c||c||}
\hline Variabel & Nilai Statistik \\
\hline \hline Skor Ideal & $\mathbf{1 0 0}$ \\
\hline \hline Rata-rata & $\mathbf{8 7 , 6 8}$ \\
\hline \hline Standar Deviasi & $\mathbf{4 , 9 1}$ \\
\hline \hline Variansi & $\mathbf{2 4 , 0 7}$ \\
\hline \hline Rentang Skor & $\mathbf{2 6}$ \\
\hline \hline Skor Maksimum & $\mathbf{9 6}$ \\
\hline \hline Jumlah Siswa yang Tuntas & $\mathbf{7 0}$ \\
\hline \hline Jumlah Siswa yang Tidak Tuntas & $\mathbf{3 9}$ \\
\hline \hline
\end{tabular}

Jika skor hasil belajar dikelompokkan dalam lima kategori, maka diperoleh tabel distribusi frekuensi seperti pada tabel 3 di bawah ini:

Tabel 3. Distribusi Frekuensi dan Persentase Skor Hasil Belajar Bahasa Indonesia Siswa Kelas X.5 SMA Negeri 11 Makassar pada Tes Hasil Belajar

\begin{tabular}{|c|c|c|c|c|}
\hline No & Nilai & Kategori & Frekuensi & Persentase \\
\hline 1 & $0-34$ & Sangat Rendah & 0 & 0 \\
\hline 2 & $35-54$ & Rendah & 0 & 0 \\
\hline \multirow{2}{*}{3} & $55-59$ & Sedang & 0 & 0 \\
\hline & $60-64$ & & 0 & 0 \\
\hline 4 & $65-84$ & Tinggi & 3 & $7,32 \%$ \\
\hline 5 & $85-100$ & Sangat Tinggi & 38 & $92,68 \%$ \\
\hline
\end{tabular}

Data ini menunjukkan bahwa ketuntasan klasikal tercapai.

\section{Respons Siswa Terhadap Kegiatan Pembela- jaran Kooperatif Tipe TGT}

Respons siswa terhadap kegiatan pembelajaran kooperatif tipe TGT berdasarkan angket yang diberikan ke siswa sebagai berikut:

\section{Respons Siswa tentang Pelajaran Bahasa Indonesia}

Tiga puluh sembilan dari empat puluh satu siswa $(97,5 \%)$ merasa senang dengan bahasa Indonesia. Dari hasil observasi juga diketahui bahwa 1 dari 40 siswa $(2,5 \%)$ menganggap bahwa pelajaran bahasa Indonesia biasa-biasa saja. Mereka beralasan bahwa 
pelajaran bahasa Indonesia baik atau tidak bergantung cara gurunya menjelaskan apakah menyenangkan atau tidak. Namun dengan adanya perangkat pembelajaran kooperatif tipe TGT ini, mereka mulai kembali menyukai pelajaran Bahasa Indonesia. Hal ini terlihat dari adanya respons positif siswa yang menyatakan bahwa mereka senang belajar bahasa Indonesia dengan menggunakan pembelajaran kooperatif tipe TGT. Selain itu, 1 dari 41 siswa menyatakan bahwa Bahasa Indonesia itu susah-susah gampang dan 2 orang siswa mengatakan bahwa bahasa Indonesia gampang-gampang susah tetapi tetap menyenangkan.

\section{Respons Siswa tentang Buku Siswa dan Lembar Kerja Siswa}

Tiga puluh tujuh dari empat puluh satu siswa (92,5\%) merasa senang dengan buku siswa dan LKS yang digunakan. Mereka beralasan bahwa penggunaan kata-kata/ penjelasan materi dan gambar-gambar yang terdapat pada Buku Siswa (BK) dan Lembar Kerja Siswa (LKS) cukup sederhana sehingga memudahkan mereka untuk mengerti materi yang disajikan. Namun demikian, 3 dari 41 siswa (7,5\%) merasa kurang senang dengan buku siswa dan LKS yang digunakan. Mereka berpendapat bahwa ada beberapa bahasa yang digunakan dalam Buku Siswa (BK) atau Lembar Kerja Siswa (LKS) yang tidak terlalu jelas. Namun secara keseluruhan, siswa tertarik dengan Buku Siswa (BK) dan Lembar Kerja Siswa (LKS) yang digunakan dan 1 dari 41 siswa mengatakan bahwa Buku Siswa dan LKS biasa saja karena sama saja yang sering didapatkan.

\section{Respons Siswa tentang Pembelajaran Kooperatif Tipe TGT}

Pada umumnya, siswa di kelas X5 SMA Negeri 11 Makassar (100\%) senang dengan pembelajaran kooperatif tipe TGT. Mereka beralasan bahwa penyajian materi yang dikaitkan dengan dunia nyata memudahkan mereka untuk memahami dengan mudah materi tersebut. Mereka juga berpendapat bahwa pembelajaran TGT memberi tanggung jawab, kerja sama dalam tim, dan menegangkan. Berdasarkan kriteria yang ditetapkan, maka dapat disimpulkan bahwa siswa memiliki respons positif terhadap perangkat pembelajaran kooperatif tipe TGT.

Berdasarkan kriteria keefektifan yang telah dibahas, maka dapat disimpulkan bahwa perangkat pembelajaran bahasa Indonesia model kooperatif tipe TGT bersifat efektif. Semua komponen keefektifan perangkat terpenuhi dan komponen, yaitu ketuntasan klasikal yang menjadi syarat utama terpenuhi.

Selain itu, berdasarkan kriteria kepraktisan yang juga telah dibahas, maka dapat disimpulkan pula bahwa perangkat pembelajaran bahasa Indonesia model kooperatif tipe TGT bersifat praktis, semua komponen kepraktisan perangkat terpenuhi.

\section{KESIMPULAN}

Berdasarkan pembahasan hasil penelitian dan ujicoba terbatas terhadap siswa kelas X5 SMA Negeri 11 Makassar, dapat diambil kesimpulan sebagai berikut:

1) Perangkat pembelajaran bahasa Indonesia model kooperatif tipe Teams Games Tournamens (TGT) pada pokok bahasan Cerpen dalam penelitian ini meliputi:
a. Buku siswa,
b. Lembar Kegiatan Siswa (LKS), dan
c. Rencana Pelaksanaan Pembelajaran (RPP).

2) Pengembangan perangkat ini menggunakan model Thiagarajan atau 4-D (Define, Design, Develop, dan Disseminate) yang meliputi empat tahap, yaitu tahap pembatasan yang mencakup lima langkah, yaitu: analisis kurikulum, analasis siswa, analisis konsep, analisis tugas, dan spesifikasi tujuan pembelajaran; tahap perancangan yang mencakup empat langkah, yaitu: penyusunan tes, pemilihan media, pemilihan format, dan perencanaan awal; tahap pengembangan yang mencakup dua langkah, yaitu: penilaian ahli dan ujicoba; dan tahap penyebaran, namun pada penelitian ini tahap penyebaran belum dapat dilaksanakan karena pelaksanaannya hanya berupa ujicoba terbatas saja.

3) Setelah dilakukan validasi dan revisi sebanyak 1 kali, perangkat pembelajaran yang meliputi Buku Siswa, LKS, dan RPP ini valid dan layak untuk digunakan berdasarkan hasil penilaian para ahli. 
4) Dari hasil ujicoba diketahui bahwa perangkat pembelajaran model pembelajaran TGT bersifat efektif dan praktis, hasil ujicoba diuraikan sebagai berikut:

a. Skor rata-rata yang diperoleh siswa pada tes hasil belajar adalah 87,68 dari skor ideal 100 dengan standar deviasi 4,91. Dimana 39 dari 41 siswa atau $92,6 \%$ memenuhi ketuntasan individu. Data ini menunjukkan bahwa ketuntasan klasikal tercapai.

b. Dengan menggunakan perangkat pembelajaran kooperatif tipe TGT, siswa jadi lebih aktif dalam proses pembelajaran. Hal ini terlihat dari 5 dari 9 kategori aktivitas siswa yang diamati dengan kategori (3), (4), (7), dan (8) yang

\section{DAFTAR PUSTAKA}

Alwi, Hasan. dkk. 2003. Tata Bahasa Baku Bahasa Indonesia Edisi Ketiga. Jakarta: Balai Pustaka.

Anonimus. 2007. Pedoman Penulisan Karya Ilmiah: Skripsi, Tesis, Disertasi, Artikel, Makalah, Laporan Penelitian, Edisi Keempat. Malang: Penerbit Universitas Negeri Malang.

Budiningsih, Asri. 2005. Belajar dan Pembelajaran. Jakarta: Rineka Cipta

Djumingin, Sulastriningsih. 2007. Pengajaran Prosa Fiksi dan Drama. Makassar: UNM

Djumingin, Sulastriningsih dan Syamsudduha. 2009. Perencanaan Pembelajaran Bahasa dan Sastra Indonesia Berbasis Kurikulum Tingkat Satuan Pendidikan (KTSP): Teori dan Penerapannya. Makassar: Badan Penerbit UNM.

Fakih, Mansour, dkk. 2004. Pendidikan Popular Panduan Pendidikan Metode Kritis Partisipatoris. Jogjakarta: STS Perdikan dan Insist Press. menjadi syarat utama dalam kriteria memenuhi Interval Toleransi PWI (\%) yang ditentukan.

c. Pada umumnya siswa memberikan respons yang positif terhadap perangkat pembelajaran yang digunakan.

d. Guru dapat membimbing kelompok bekerja dan belajar. Hal ini terlihat dari 5 kategori aktivitas guru yang diamati yang menjadi kriteria memenuhi Interval Toleransi PWI (\%) yang ditentukan.

e. Tingkat kemampuan guru dalam mengelola proses pembelajaran kooperatif tipe teams games tournamens (TGT) termasuk dalam kategori sangat tinggi, artinya penampilan guru dapat dipertahankan.

Nurhusain, Muhammad. 2009. "Pengembangan Perangkat Pembelajaran Matematika Kooperatif Tipe Teams Games Tournaments (TGT) Dengan Pendekatan Contextual Theacing And Learning (CTL) Pada Siswa Kelas VII 1 SMP Negeri 26 Makassar." Skripsi. tidak diterbitkan. Makassar: Program Sarjana FMIPA UNM."

Patombongi, A. Wardihan, dkk. Telaah Kurikulum Bahasa Indonesia. Makassar: UNM

Somad, Adi Abdul, dkk. 2008. Aktif dan Kreatif Berbahasa Indonesia 1 untuk SMA/MA Kelas $X$. Surabaya: JP Books.

Suprijono, Agus. 2009. Cooperative Lear

Trianto. 2009. Mendesain Model ning: Teori dan Aplikasi PAIKEM. Yogyakarta: Pustaka Pelajar. Pembelajaran Inovatif, Progresif, Konsep, Landasan, dan Implementasinya pada Kurikulum Tingkat Satuan Pendidikan (KTSP). Jakarta: Kencana. 